\title{
The Value of Patient Care in the New Economy
}

\author{
Darlene R. Desir \\ 17815 80th street North \\ Loxahatchee FL 33470 \\ Tel:+1-561-429-4182Ｅ-mail: dd866@nova.edu
}

Nile M. Khanfar (Corresponding author)

Nova Southeastern University

3970 RCA Blvd., Suite 7006

Palm Beach Gardens, Florida 33410

Tel: +1-561-622-8682, ext. 5642 E-mail: khanfar@nova.edu

Catherine Harrington

Nova Southeastern University

3970 RCA Blvd., Suite 7006

Palm Beach Gardens, Florida 33410

Tel: +1-954-262-5665 E-mail: ch562@nova.edu

David Loudon

Samford University

800 Lakeshore Drive

Birmingham, AL 35244

Tel: +1-205-726-4314Ｅ-mail: dlloudon@samford.edu

Received: February 18, $2011 \quad$ Accepted: April 13, 2011 doi:10.5430/jms.v2n2p23

\begin{abstract}
Delivering superior customer service is as important as delivering superior patient care. To survive in this economy, organizations need to differentiate themselves from their competitors. They need to have customer feedback in order to implement the strategies needed to increase organizational performance level, profits and revenues. The purpose of this case is not about the layoffs that took place in one of the best places to work, but more about the reasons why the organization had to make such decisions. We will evaluate the marketing strategies, management processes and organizational goals, to determine how customer service can literally cause a leading organization to be at its worst (Note 1).

Keywords: Customer service, Management, Marketing strategies, Healthcare

On July 31, 2008 the entire laboratory at Lincoln Memorial Medical Center (LMMC) was experiencing mixed feelings. Some people were content with their salary increase and performance evaluation, while others were not. Gina, a Filipino girl with a master's degree, was feeling quite happy. As a single mother of four, things were looking great for her. She had finished college, her divorce was final, and her immigration status was on the right track. This day, she thought, was going to be great. Around 3:00PM, she received a call from the lab director, asking her to come to his office. The call didn't seem strange, for she had to give reports from time to time. As she arrived in the office, with a big smile on her face, she was greeted by the lab director, and the chief of operations.
\end{abstract}


Director: Hi Gina, this is Sandra the COO, have a seat, we have a few things to discuss with you.

Gina: Hi Sandra. (she sits)

Director: Were you happy about your increase?

Gina: Oh yes, very happy. Thank you very much.

Director: That's good, you deserve it.

Gina: Thank you.

Sandra: Well Gina, the reason we asked you to in here is because, unfortunately, we have to let you go. We understand this is short notice, but you have to leave the premises as soon as possible. We prepared a severance package for you, and we will pay you for the entire day. We are truly sorry, but we must do what's best for the company at this time.

Gina: I don't understand. (shaking and in shock)

Director: We have all your belongings ready for you. You have to leave. Security.....

Gina: Security? What did I do wrong? Why do I need security called on me?

Director: Gina, we need you to leave.

Gina: Okay.

Gina got up, grabbed the box that another manager had brought containing her belongings and walked to her car. She sat there for ten minutes because she was unable to move. Finally, she called her son to pick her up. As she was waiting in the parking lot, the director walked up to her, and told her she couldn't remain or security would be called. It is at that moment, she remembered being with the organization for five years and never having been in trouble. Her tears started to pour. The reason for her termination, and those of many, will be discussed in this paper.

\section{Organizational Culture}

\subsection{Labor-employee Relations}

Lincoln Memorial Medical Center, located in Florida is one of many hospitals in a large chain hospital network system. The network's value proposition was to enhance the quality of care in communities, reduce cost, and improve the economy. As the network grew its value propositions continued to be based on its original principles, and their main focus became better patient care. LMMC had been a non-profit hospital for many years. The 400-bed hospital was known for its specialization in open-heart surgery, oncology, and orthopedics. It had joined the large network in the 1990s. The buyout of LMMC was a wise business decision, as the hospital was known to be a respectable provider of quality patient care. At the time, there weren't many competitors in its geographical area, and the ones that existed weren't performing as well as LMMC. Prior to 2008, LMMC had received many favorable ratings for their quality in-patient care and employee satisfaction. By early 2008, many employees had begun to worry about their job safety, which led to an increase sick leave usage. Although management reassured everyone that their jobs were secure, employees were still concerned about their job security. As a lead medical tech at LMMC, Rhonda needed answers to the many questions asked by her co-workers every day. Consequently, she asked to speak with her Director.

Director: Hi Rhonda, what brings you to my office today?

Rhonda: Well, my co-workers and I were wondering if our jobs were in danger?

Director: Unfortunately, I can't answer that question honestly. For now, I can say it's ok, but if corporate tells me I have to cut staff, then I must.

Rhonda: Why would they want to cut staff?

Director: Well because we are not making the numbers.

Rhonda: We could cut hours, but a layoff is just too much.

Director: It's a corporate decision.

Rhonda: I see. Thanks for your time.

Director: You're welcome.

As she walked out of the office, Rhonda just had an ache in her stomach because she couldn't imagine anyone getting laid off in the recessionary economy. She also started thinking about the phrase "not making the numbers." Things were unusually slow for that time of the year, but everyone thought things would pick up. However, the real reason for the slowdown was soon identified: it was poor quality. 


\subsection{Customer Evaluations}

The patient's perception of quality healthcare had changed significantly over the last fifteen years. In the mid 1990s, the economy was strong. Although insurance companies have always played a major role in the amount of care or treatment a patient receives, it didn't affect the willingness of the patient to pay the difference if it seemed necessary. In today's weak economy, with the cost of healthcare rising and insurance companies paying less, patients are making quality healthcare a priority. Quality healthcare refers to the quality of service received from the time patients are admitted to the time they are discharged. Medicare is monitoring patient services. If a patient does not rate the hospital with a good score, the facility will not be reimbursed by Medicare.

\section{Total Quality Management (TQM)}

\subsection{Quality Improvement}

In 2008, LMMC was second to last, for quality service in its network. To go from one of the best healthcare facilities to being one of the worst, was certainly a disappointment for management. The corporation began to put pressure on management to solve this problem. This meant they had to put on their thinking hats and implement effective and efficient strategies to increase the organization's performance level. The corporation generated two surveys: an employee survey called the "Employee engagement survey", and a customer survey called HCAAPS (Hospital Consumer Assessment of Healthcare Providers and Systems). On the HCAAPS, the patient was asked to rate the facility on such dimensions as cleanliness, professionalism, nursing staff, physicians, the food, and laboratory services. It was noticed that the lowest scores were of the nursing staff and the physicians. The patients complained about the lack of care received by both the nurses and the physicians. Such results were clearly responsible for the decrease in customer loyalty. Although hospitals are not people's favorite place to be, the facility must position itself so that the customer will always choose that particular hospital, in case of a medical emergency. LMMC's reputation was so bad that the patients were choosing its competitors, including St. Francis Medical Center, Lakeside Memorial Hospital and Coastal Medical Center. Along with the marketing department, management must look at low scores and high scores, to find solutions that will satisfy both the customers and the employees. On the basis of its analysis LMMC decided to undertake several strategies:

1) They implemented mandatory online customer service courses for all employees

2) They enacted a "Bright Ideas" program involving employees in finding innovative ideas that would work towards fulfilling organizational goals

3) They worked to further build a relationship with the customer by keeping a diary-like notebook by each patient's side, and having them make daily notes

4) They established an employee counsel group to gain employee feedback about how to create a better working atmosphere.

Quality can be defined as providing goods and services that completely satisfy the needs of internal and external customers (Johnson, William and Weinstein, Art, Delivering Superior Customer Value in the new Economy, p76). Because LMMC wanted to satisfy the employees, who are the internal customers and who provide services to patients (its external customers), the counsel group along with management implemented certain initiatives to increase the organization's performance. Using the six sigma approach, they defined the process needed to create a friendlier atmosphere at LMMC. It became hospital policy that if any employee was rude to either a patient or another co-worker, they would be terminated. Although that may sound extreme, the medical center was dedicated to keeping only employees who could provide superior service. Service companies must retain only the best personnel in order to win and keep good customers. However, what LMMC failed to acknowledge was the shortage of high-quality staff. If employees are not given enough support by an organization by providing enough people, they leave. This decreases the employee retention rate and can become another problem. As we all know, in the business world, whether the economy is going in the right direction or not, the main objective of an organization is to maximize economic profit. How this objective is achieved depends on the business decisions of the managers (Thomas, Christopher R. \& Maurice, Charles S., Managerial Economics-Foundations of Business Analysis and Strategy, pp14-16). The mission statement of LMMC states that they want to be the community's leading choice of healthcare provider and to provide the highest quality of patient care. Organizations have a mission statement because it is a promise made to the customers. However, what companies fail to recognize is that the promise cannot be kept, if their strategic choice, which is how an organization will attempt to fulfill its mission and achieve its long-term goals, does not include its primary resource, the employees(Noe, Raymond A. et al, Human Resource Management, Gaining a Competitive Advantage, pp81-82). It makes sense for managers to show customers they are valued, because it creates loyalty and contributes to organizational 
goals. It also makes sense for managers to show their employees they are valued, because those employees provide the services to the customers, and they contribute in the economic profit of the organization.

Lincoln Memorial Medical Center also changed its image. Although image is not everything, it can play a major role in the successful marketing of an organization (Johnson, William and Weinstein, Art, Delivering Superior Customer Value in the new Economy, p127). LMMC made improvements to its front lobby by enlarging it. They also added new parking spaces to better accommodate patients and their visitors, and they added a flat screen television in the cafeteria. Since the medical center is a prime cardiac hospital, it strongly supports the American Heart Association. The employees increased awareness by raising money and participating in the association's heart walk. This was part of their commitment to social responsibility as an organization. The term social responsibility may be defined as taking an active part in the social causes and civic life of one's community and society. It can improve the quality of life and the economy (Cavico, Frank J. and Mujtaba, Bahaudin G., The Moral Foundation of Effective Leadership, Management, and Entrepreneurship, pp 162-163). Organizations involved in improving the life of the community not only attract customers because people want to be associated with such organization, but they create loyalty, which is an effective marketing strategy. Loyalty not only will improve the organization's performance but it will also increase customer retention rates, which increases market value (Johnson, William and Weinstein, Art, Delivering Superior Customer Value in the New Economy, p187).

As part of their technological leadership skills and as a way to differentiate themselves from the competitors, LMMC Medical Center became a center for an exclusive robotic radiosurgery system. This evidenced the medical center's advancement in the technological world. The hospital was able to offer a cancer treatment without invasive surgery which could help increase the quality of life of patients, who would be able to resume their daily activities more quickly after receiving treatment. This innovation was a value added benefit for LMMC because it showed the organization cares for its patients. This created a strong relationship with patients. The organization that is different may not be better, but it has a good chance of being seen as innovative and superior (Johnson, William and Weinstein, Art, Delivering Superior Customer Value in the New Economy, p164). In their research paper, Innovation in Healthcare delivery Systems: A Conceptual Framework, authors Vincent Omachonu and Norman G. Einspruch defined innovation as the introduction of a new concept, idea, service, process, or product aimed at improving the treatment, diagnosis, education, outreach, prevention, and research, and with the long term goals of improving quality, safety, outcomes, efficiency and costs. New technology alone does not guarantee the survival and the sustainability of a new service. The true test of an innovation lies in whether it could provide new value for users and the general public (Lin, Shu-Hsia, et al. A business model analysis of telecardiology service).

The department that had made the greatest negative impact on the performance level of LMMC was the emergency room (ER). Patients complained that ER waiting time was worse than all of its competitors. As part of its process redesign, LMMC responded to its customers' need for a shorter waiting time, LMMC expanded its emergency department by adding an auxiliary department adjacent to the ER. The department is considered a holding area for the patient who has been seen by the physician, and the physician is waiting for laboratory or radiologic results to determine if the patient gets admitted to another floor, or gets discharged. They also provided each physician with a Personal Digital Assistant, which is an electronic device that doctors could carry with them to order the necessary tests for a patient. Not only did this decrease paperwork but also was part of becoming more technological. The device also provided the laboratory with a tracker, which is a monitor screen that helps the technicians and the physicians keep track of delayed tests results. Such effort improved the turnaround time for receiving laboratory test results. Patients were also able to access the waiting time situation in every hospital in the chain on its website. This turned out to be a great way to keep patients informed, especially those whose primary source of communication is social media.

\subsection{Control and Evaluation}

Unfortunately, besides Gina, LMMC had to terminate about 60 employees. Although it was a rough time for the organization and those who were let go, since that time there haven't been any further layoffs. That helps confirm the wisdom of the improvements LMMC made and indicates that the organization is moving in the right direction. The latest HCAAPS scores improved, but were not as high as management wanted them to be. However, the facility continued to make improvements in the processes, and believes in making quality patient healthcare an everyday priority. The past year's employee engagement survey showed that the lowest scores were in staffing. LMMC had not been able to increase its staffing scores for two years. The results may have been due to the shortage of nurses and technologists in the area. Management made this weakness their focus to increase the score for next time. Incentives may need to be given to attract candidates. 
In May 2009, while at a wedding, Rhonda encountered Gina. After making small talk about the bride, the subject of the layoff came up.

Rhonda: What did you do after you left the premises?

Gina: I went home and told my kids. It wasn't too hard at first because they gave me the severance package. But after that money was gone, that's when it became hard.

Rhonda: How did you support yourself Gina?

Gina: I couldn't get a job with my MBA degree, because my immigration papers weren't completed. So I cleaned houses in the meantime to feed my kids.

Rhonda: Wow! That must have been hard. How did you cope with all of this?

Gina: I was okay. As long as my kids were fed, I was okay. It hurts from time to time, when I think about the way I was let go. It was humiliating, but I'll be alright. Now I'm working with pregnant teens and I feel good because I'm helping someone.

Rhonda: Good for you Gina.

In order for an organization to compete in this tough economy, it needs to have effective and efficient strategies. The strategies need to be implemented correctly. This is critical to avoid negative entropy. It creates value. Those strategies need to be adaptable to whatever changes occur within the organization, whether it be technical or economical. An organization needs leaders who will know how to create and implement strategies to enhance organizational performance, increase profits and revenues, and meet organizational goals. That is why leadership involves the head and the heart. It is both analytical and interpersonal. Having the range and repertoire to be calculating, rational, and decisive at times and at other times compassionate, nurturing, and participative, and knowing when to be which, is a huge challenge (B. Joseph White, The Nature of Leadership, p 4). Managers must make organizational decisions while keeping in mind their employees. An organization must invest in its Human Resource department, because when aligned with the business strategy, it gains a competitive advantage. When employees feel valued, motivated, safe and empowering, they provide a level of service incapable of being duplicated by the competitors. Every individual perceives value differently. However, every individual wants superior value delivered to them. No one wants to do business with a company that doesn't value its customers, and rarely do customers like to do business with a company that doesn't value its own employees. Negative attitudes will often transfer to personnel-client relationships. This is why having good employee morale is highly valued in the business world (Nordstrom, Edward Jones, Publix to name a few). Progressive companies that create maximum value for their customers will survive and thrive. Superior customer value means continually creating business experiences that exceed customer expectations (Johnson, William and Weinstein, Art, Superior Customer Value in the New Economy, pp 4-5). That is how loyalty is created.

\section{References}

Bacigalupe, Gonzalo (2011). "Is there a role for social technologies in collaborative healthcare?" Families, Systems \& Health 29.1 (2011): 1+. Academic OneFile. Web. 9 Apr. 2011.

Cavico, Frank J., \& Mujtaba, Bahaudin G. (2009). Business Ethics. The Moral Foundation of Effective Leadership, Management, And Entrepreneurship. Corporate Governance: Legal and Moral Issues, 12,162-163.

Johnson, William and Weinstein, Art. (2004). Superior Customer Value in the New Economy 2nd Edition. Florida, Boca Raton: CRC Press.

Omachonu, Vincent K. \& Einspruch, Norman G. Innovation in Healthcare Delivery Systems: A Conceptual Framework. The Innovation Journal: The Public Sector Innovation Journal, vol.15(1), 2010, article 2.

White, Joseph B. \& Prywes, Yaron. (2007). The Nature of Leadership. New York, NY: AMACOM

\section{Notes}

Note 1. All individuals, companies, and locations are disguised in this case. The authors developed this case for class discussion rather than to illustrate either effective or ineffective handling of the situation. 